研究課題別研究評価

1. 研究課題名： 微小管を介した情報伝達の一分子イメージング

2. 研究者名: 武藤 悦子

3. 研究の狙い:

私は ATP 存在下で、モ一タ一蛋白キネシンが、微小管上数 $\mu \mathrm{m}$ という広い範囲にわたつて協同的に 結合することを見出した。このことはキネシンが運動中に、相互作用している微小管の側に、キネシンに 対する親和性を増加するような状態変化がおきていることを意味している。本研究の第 1 の狙いは、微 小管に蛍光色素を標識し、その状態変化を蛍光スペクトルの変化として検出することのできる実験系を 作ること、そしてこのことを利用して最終的には、微小管の状態変化を 1 分子顕微鏡下で視覚化できるよ うにすることである。つまり一言でいえば、微小管の状態変化を「視る」ことのできる実験系をつくることに ある。そして第 2 の狙いは、状態変化を起こしている時の微小管に一体何が起きているのか、その実体 に迫りたい。そのための1つのアプローチは外界からの電場、磁場などによって Perturbation を与え、微 小管の状態変化に変調を与える試み(結果の (3))であり、もう1つのアプロ一チは協同的結合の詳細な 解析による、正確な現象の記述(結果の (4))である。

\title{
4. 研究結果及び自己評価
} 研究結果

（1）チューブリンのリジン残基に蛍光修飾をした場合、クアマリンやフルオレセインなどの色素 では、微小管の状態変化に伴って蛍光強度の減少が観察され、一方、NBDやダンシル、ピンポなどの色 素では蛍光強度の増加が観察された。しかしいずれの場合も蛍光強度の変化はわずかであり、イメージ ングに利用できるような顕著なスペクトル変化は認められなかった。これらの複数の蛍光色素から得ら れたデータを総合的に考察した結果、キネシンの運動に伴って、蛍光色素の導入されたリジン残基の周 囲の環境は疎水的に変化しているらしいことが明らかになった。

（2）リジン残基に導入した蛍光色素では、顕著なスペクトル変化を得ることができなかったので、

チューブリン分子の $\beta$ 鎖 $\mathrm{C}$ 末近傍にあるグルタミン酸残基に、特異的に蛍光色素を導入する方法を新た に開発した。このサイトに蛍光色素ダンシルを導入した場合、キネシン分子の rigor 結合に伴って蛍光ス ペクトル強度が増加するのが観察された。しかし ATP 存在下でキネシンとの相互作用に伴って起こる微 小管の状態変化については、残念ながらこれまでにいかなる色素においてもスペクトル変化は認められ ていない。

（3「外部から Perturbation を与えることによって、キネシンによって誘導される微小管の状態 変化に、何らかの変調を起こすことができないだろうか? 」という意図から、微小管に様々な周波数と電 圧の電場を与え、キネシンの運動に与える影響を調べたが、少なくともこれまでに試した範囲では電場 の影響は全く現れなかった。

(4)キネシンコートしたビーズが微小管と相互作用する様子について、さらに詳細な統計的解析 を行った結果、以下のことが明らかになった。

(4-a)ATP 存在下では、微小管上を動いているキネシンビーズの近傍数 $\mu \mathrm{m}$ の範囲で、新たな キネシンの結合が起こりやすくなっている。

(4-b)ATP がない時あるいは AMPPNP 存在下では、キネシンビーズの微小管への結合はラン ダムに起きている。

(4-c)ATP 存在下、協同的結合は微小管上に既に結合しているキネシンの+側で起こり易い

(4-d)一方キネシンが微小管上を動いている時には、協同的結合はその十側と一側で大体 $2: 1$ の確 率で起きている(一側の結合は履歴による)。 
自己評価

当初の目的であったイメージングに関しては、期待するほどの顕著なスペクトル変化を示す色素を見 つけることができずに終わってしまった(結果の(1),(2)参照)。しかしリジン残基に蛍光色素を修飾した場 合、複数の蛍光色素で、微小管の状態変化に伴って色素周辺の疎水性傾向が強くなるという結果が得 られているので、やはり微小管には何らかの変化が起きているのだと考えられる。さきがけの期間の中 では分子生物学的手法による分子改変にまで手を出す余裕がないと考えたので、手近なリジン残基あ るいはグルタミン残基をそのまま利用して、ともかく手に入る色素は全て試してみたわけだが、結局それ ほど簡単にはいかなかった。今後はもっとじっくりチューブリンの発現系を作るところから取り組んで、分 子改変によりチューブリン上の色々な場所で蛍光修飾を試み、時間はかかってもスペクトル変化をクリア ーに検出できる実験系を作っていきたい。

一方キネシンの協同的結合の詳細な解析からは、これまで不可思議に思われた事実や、わからなか った点が解決され、微小管のダイナズムを統一的に理解することができたと思う(結果(4)参照)。「数 $\mu$ $\mathrm{ml}$ にぶ状態変化」や「数秒に及ぶ履歴」は、一見これまでの常識からはかけ離れているように思える が、この2つの特徵にこそ現象のメカニズムを解く鍵があるように思えてならない。1つの可能性としては、 大沢らが昔 Polyelectrolyte の理論的研究で示唆したように、そして Cantiello らが直接アクチンで検出し たように、高分子ポリマーの表面にあるカウンターイオンの動きが何らかのメカニズムで整流されて、そ の結果ポリマー表面に非線形の電流が流れているのではないだろうか？ 電場による Perturbation の 実験は大した成果が得られなかったわけだが(結果(3)参照)、実験のやり方がまずかった可能性も充分 に考えられるので、今後はこの分野の研究者と緊密に連絡を取り合って、なお慎重に可能性を調べてい きたい。最後に(4-c)、(4-d)の結果は、微小管とキネシンの相互作用ポテンシャルに異方性があることを 示しており、近年提唱されているキネシンのブラウン運動モデルとも関連して、この異方性ポテンシャル がキネシンの運動を一方向に導いている可能性も考えられ、今後の展開が大変興味深い。

\section{5. 領域総括の見解}

蛍光ラベル法によってモーター蛋白質キネシン分子の微小管上の運動を追跡して、ATP 存在下でキ ネシンが動いている近傍で他のキネシンが微小管に結合しやすくなることを実証した。これはキネシンと 微小管チューブリンの相互作用によると考えられ、蛋白質のダイナミックな構造変化からみて大变興味 深い発見である。ただし、その分子構造変化の解明は容易ではない。

\section{6. 主な論文等}

1) Miyamoto $Y$, Muto E, Mashimo T, Iwane AH, Yoshiya I, and Yanagida T. Direct inhibition of microtubule-based kinesin motility by local anesthetics.

Biophys.J. 78:940-9 (2000)

2) Nishiyama $M$, Muto $E$, Inoue $Y$, Yanagida $T$, and Higuchi $H$. Sub-steps within the 8nm step per ATPase cycle of single kinesin molecules. Nature Cell Biology., in press..

3) Inoue $Y$, Iwane $A H$, Miyai $T$, Muto $E$, and Yanagida $T$. Movement of single one-headed kinesin molecules along microtubules. Submitted.

4) Muto E, Miyamoto $Y$, Funatsu T, Harada $Y$, Iwane AH, Ishijima $A$, and Yanagida $T$.

Long-range cooperative binding of kinesin to a microtubule in the presence of ATP.

Submitted. 